\title{
The Impact of Inflation and Unemployment on Subjective Personal and Country Evaluations
}

\author{
Néstor Gandelman and Rubén Hernández-Murillo
}

\begin{abstract}
The authors use data from the Gallup World Poll to analyze what determines individual assessments of past, present, and future personal and country well-being. These measures allow the analysis of two dimensions of happiness data not previously examined in the literature: the better-than-average effect and optimism. The authors find that individuals tend to evaluate their personal well-being as being better than their country's and tend to expect that their future well-being will improve. The authors also analyze the impact of inflation and unemployment on these subjective measures and find that both variables have a negative effect on individuals' assessments of past and present well-being for themselves and their country; in contrast with other studies, however, they do not find that the effect of unemployment is significantly different from that of inflation. (JEL D60,
\end{abstract} I30, E31, E24, Z13)

Federal Reserve Bank of St. Louis Review, May/June 2009, 91(3), pp. 107-26.

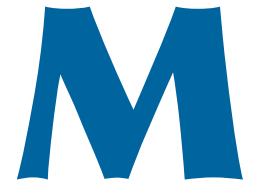

easuring the impact of economic policies on personal well-being is at the heart of most applied research. Traditionally, economists have been reluctant to use self-reports of wellbeing-or happiness-for policy evaluation because of their subjective nature. Instead, economists prefer to infer individual preferences from observed choices and evaluate the impact of policies with these choices and derived preferences. As Di Tella and MacCulloch (2006, p. 25) state, "economists typically watch what people do, rather than listening to what people say."

Easterlin's (1974) seminal paper is the first to seriously make use of self-reported happiness data. In this study, he documented that although happiness responses are positively correlated with individual income at a given point in time, self-reports of happiness in the United States had remained stagnant while average personal income increased over time. This pattern, often called the "Easterlin paradox," has also been observed in other countries (Veenhoven, 1993; Blanchflower and Oswald, 2004). One of the most favored explanations for this apparent puzzle in the literature is that individuals' happiness is determined by their income relative to other people's income; that is, they derive happiness not only from the levels of consumption attained with income, but also from their position in the income (and consumption) distribution relative to other members of their communities (Easterlin 1974, 1995, and more recently Di Tella and MacCulloch, 2006).

Although Easterlin's study was noted by some scholars when it was published, it took time for academics to engage in subjective data research to a substantial degree. Since the late 1990s the amount of research making use of happiness and satisfaction databases has increased considerably (see Frey and Stutzer, 2002, for a recent review of

Néstor Gandelman is a professor of economics at Universidad ORT Uruguay, and Rubén Hernández-Murillo is a senior economist at the Federal Reserve Bank of St. Louis. The authors thank the Inter-American Development Bank (IADB) and the Gallup Organization for facilitating access to the Gallup World Poll. This paper was written as background material for the Inter-American Development Bank 2009 Economic and Social Progress Report in Latin America. Christopher Martinek provided research assistance.

(C) 2009, The Federal Reserve Bank of St. Louis. The views expressed in this article are those of the author(s) and do not necessarily reflect the views of the Federal Reserve System, the Board of Governors, or the regional Federal Reserve Banks. Articles may be reprinted, reproduced, published, distributed, displayed, and transmitted in their entirety if copyright notice, author name(s), and full citation are included. Abstracts, synopses, and other derivative works may be made only with prior written permission of the Federal Reserve Bank of St. Louis. 
the literature). To measure the different concepts of satisfaction, well-being, and happiness, social scientists use nationally representative household surveys. For instance, past research has used the British Household Panel Survey (BHPS), the American General Social Survey (GSS), the German Socio-Economic Panel (GSOEP), Eurobarometer, Latinobarometro, the European Community Household Panel (ECHP), the Russia Longitudinal Monitoring Survey (RLMS), the International Social Survey Programme (ISSP), and the World Values Survey (WVS).

This paper uses the 2006 Gallup World Poll dataset. This newly designed survey contains information about an individual's assessment of her or his current, past, and future personal wellbeing and assessments of her or his country's current, past, and future well-being. With this novel dataset we do three things: (i) We examine the determinants and the effects of inflation and unemployment on past, present, and future individual assessments of personal and country wellbeing. (Previous studies have analyzed only personal assessments of current well-being.) (ii) We examine two aspects of happiness data that have not been previously addressed in the literature: First, comparing personal and country evaluations, we test for the better-than-average effect discussed in the cognitive psychology literature; then we construct measures of personal and country optimism comparing future and present evaluations and examine their determinants. Finally, (iii) we report some contrasting findings on the indirect preferences for inflation and unemployment implied in happiness reports.

The better-than-average effect refers to the tendency to overestimate one's personal traits or abilities (e.g., overrating one's own looks or the ability to drive; Caliendo and Huang, 2007). The better-than-average effect has been linked in the finance and economics literature to apparently irrational behavior because individuals are thought to exhibit an unrealistic, or overconfident, image of themselves. Camerer and Lovallo (1999), for example, study whether overconfidence leads to excess entry by firms. Caliendo and Huang (2007) argue that overconfidence about the average return on savings can have large effects in the work-life consumption profile in a life cycle model. In the finance literature, Chuang and Lee (2006), among others, have studied overconfidence linking investors' behavior to apparently anomalous phenomena. They argue that overconfident investors underestimate risk, trade in riskier securities, overreact to private information, underreact to public information, and trade more aggressively in subsequent periods after observing market gains. Benoît, Dubra, and Moore (2009) and Benoît and Dubra (2009), on the other hand, dispute the traditional interpretation that the better-than-average effect is a sign of irrational (overconfident) behavior. We do not concern ourselves in this paper with the relation between the better-than-average effect and the possibility of overconfidence. Rather, we consider that if individuals tend to describe their own well-being as better than the averagethat is, better than their country's-the determinants of subjective well-being reports on personal and country evaluations do not need to be the same.

Most research using data from the Gallup World Poll (which began in 2005) has been published in the Gallup Management Journal. Because of copyright issues, the use of this database has been very restricted. To the best of our knowledge, only two papers in the economics literature have used these data: Deaton (2008), in a study of the effect of national income, age, and life expectancy on assessments of health satisfaction and general satisfaction with life; and Stevenson and Wolfers (2008), in a study on reassessing the Easterlin paradox. ${ }^{1}$ Using data for many countries and over many years, Stevenson and Wolfers established, in contrast with Easterlin (1974), a positive link between average levels of subjective well-being and gross domestic product (GDP) per capita across countries; they also found evidence that, within countries, economic growth is associated with increasing happiness.

In addition to the connection with personal income, data on self-reports of well-being have

\footnotetext{
1 Recently the Inter-American Development Bank published the book Beyond Facts: Understanding Quality of Life (Lora, 2008), which uses this database extensively to specifically describe Latin American and Caribbean countries.
} 
also been used to analyze other implications of public policy. Clark and Oswald (1994), for example, used data from the BHPS to assess the utility levels of the unemployed. They find that unemployed people in Great Britain in 1991 had much lower levels of well-being than employed individuals. Recent studies on the economics of happiness include a paper by van Praag, Frijters, and Ferrer-i-Carbonell (2003) that analyzes the determination of an individual's self-reports of satisfaction with several aspects of life and how these combine into self-reports of general satisfaction with life. The authors used the GSOEP in their analysis. Scoppa and Ponzo (2008) analyze the determinants of individual subjective well-being in Italy. These authors used data from the Survey of Household Income and Wealth conducted by the Bank of Italy. Among other findings, they also report that individuals care about relative income. Several other applications of happiness data are discussed in the survey by Di Tella and MacCulloch (2006).

The literature has also analyzed the effect of macroeconomic variables on self-reports of life satisfaction and the implied preferences over inflation and unemployment. Di Tella, MacCulloch, and Oswald (2001), for example, analyzed whether the one-to-one marginal rate of substitution implied by the so-called misery index (the sum of the unemployment rate and the inflation rate) is validated in self-reports of happiness data. ${ }^{2}$ In a different study, Di Tella, MacCulloch, and Oswald (2003) analyzed the impact of macroeconomic variables (including GDP per capita levels and growth in addition to inflation and unemployment) on happiness reports; they also examined the psychological cost of recessions (in excess of the fall of GDP and the rise in unemployment) implied by the happiness reports. The authors used data from Eurobarometer for 12 European countries between 1975 and 1995 and from the American GSS for the period 1972-94. They find that-in contrast to the common assumption-at the margin, unemployment seems to cause more unhappiness than inflation and conclude that the

\footnotetext{
2 The misery index was introduced by Arthur Okun in the 1960s as a straightforward indicator of the social costs of inflation and unemployment (Lovell and Tien, 2000).
}

misery index underestimates the welfare cost of unemployment. Blanchflower (2007), using data from the World Database of Happiness for 25 Organisation for Economic Co-operation and Development (OECD) countries for 1973-2006, finds results consistent with those of Di Tella, MacCulloch, and Oswald (2001). In a related study, Wolfers (2003) finds evidence that inflation and unemployment lower perceived well-being and that macroeconomic volatility, especially unemployment volatility, also undermines wellbeing. Jayadev (2008), using data from the 1996 ISSP for 27 countries, studied the preferences of different socioeconomic classes over inflation and unemployment. The author found that the "working class," defined as those with lower occupational skills and economic status, is more likely to rank minimizing unemployment as a higher priority than maintaining low inflation. Easterly and Fischer (2001), using a 1995 survey of 38 countries (19 developed and 19 developing and transition countries), portray a different picture. They report that the poor are more likely than the rich to mention inflation as a top national priority. Lastly, Peiró (2006) also explores different microeconomic and macroeconomic determinants of happiness.

This paper is organized as follows. In the next two sections we present the data and describe the estimation strategy. We then present our study results, followed by our conclusions.

\section{DATA}

The source for the personal and country evaluation is the Gallup World Poll. The Gallup World Poll is probably the world's most comprehensive database of behavioral economic measures. It surveys citizens in more than 140 countries, representing about 95 percent of the world's adult population. Our dataset contains responses from about 70,000 individuals in 75 countries for the year 2006 .

In the research on the economics of happiness, the happiness measure, the key variable of analysis, is often constructed with the answer to a question; and the question is typically worded 
in one of two ways: "Taking all things together, would you say you are: very happy, quite happy, not very happy, or not at all happy?" or "All things considered, how satisfied are you with your life as a whole?" The possible answers for the latter range from "very dissatisfied" to "very satisfied," also with four or five possible responses.

The question on personal assessment in the Gallup World Poll is an example of the second form, in which the responses use a ladder analogy. The question is "Please imagine a ladder/mountain with steps numbered from zero at the bottom to ten at the top. Suppose we say that the top of the ladder/mountain represents the best possible life for you and the bottom of the ladder/mountain represents the worst possible life for you. If the top step is ten and the bottom step is zero, on which step of the ladder/mountain do you feel you personally stand at the present time?"

The Gallup World Poll includes additional questions on the individual's status 5 years ago: "On which step of the ladder/mountain would you say you stood 5 years ago?" And it includes expectations for the future: "Just your best guess, on which step do you think you will stand on in the future, say 5 years from now?"

The questions on country assessment in the Gallup World Poll are almost identical to the questions on one's personal situation: "Once again, imagine a ladder with steps numbered from zero at the bottom to ten at the top. Suppose the top of the ladder represents the best possible situation for (name of country) and the bottom represents the worst possible situation. Please tell me the number of the step on which you think (name of country) stands at the present time." The survey also includes an assessment of the country's past situation: "What is the number of the step on which you think (name of country) stood about 5 years ago?" and the expected future: "And just your best guess, if things go pretty much as you now expect, what is the number of the step on which you think (name of country) will stand about 5 years from now?"

The measures of personal and country wellbeing in our dataset therefore range from zero to ten. We also constructed two additional variables to capture "optimism" regarding personal and country assessments. The optimism variables are defined as the difference between the answer to the "future" and "present" questions. These variables, of course, range from -10 to 10 .

The Gallup World Poll has many individuallevel variables that can be used as controls in the estimations, including the sex, age, marital status, employment status, location of residence (urban versus rural characteristics) of the respondent, and a categorical proxy for personal income. ${ }^{3}$ We complemented the survey data with country measures from the World Development Indicators database on inflation and unemployment for the period 2002-05 (World Bank, 2007).

Table A1 of the appendix lists the countries in our sample, along with the averages for the dependent variables used in the analysis and their macroeconomic indicators for 2005.

\section{ECONOMIC STRATEGY}

Our estimation strategy is a variation of the methodology used by Di Tella, MacCulloch, and Oswald (2001). Our study differs from theirs in that they study a small cross section of European countries over several years, whereas we examine a larger set of countries from different regions of the world for only one year. More importantly, Di Tella, MacCulloch, and Oswald examine only life satisfaction as the dependent variable, and we analyze eight measures of happiness as dependent variables: current life satisfaction, past life satisfaction ( 5 years ago), expected future life satisfaction (in 5 years), life satisfaction optimism (defined as future minus present satisfaction), current country situation, past country situation (5 years ago), expected future situation (in 5 years), and country satisfaction optimism (defined as future minus present country situation).

In our estimations, we follow two basic approaches. The first approach is similar to the two-step procedure used by Di Tella, MacCulloch, and Oswald (2001). In the first step, we run an ordinary least squares (OLS) regression of each

\footnotetext{
3 Additional variables not used in the current study include importance of religion, number of children, characteristics of current housing, and others.
} 
variable of interest against a set of individual characteristics identified by the literature as affecting happiness and satisfaction levels. ${ }^{4}$ We include country fixed effects and cluster the standard errors by country. The average residuals of this first regression for each country (including the estimated fixed effect) can then be interpreted as the average assessment of personal or country satisfaction that is not explained by individual characteristics. The second step of this approach then runs an OLS regression of the country-level averages of the residuals on inflation and unemployment. The estimated coefficients in the second stage are then interpreted as in Di Tella, MacCulloch, and Oswald (2001) as the impact on well-being from a 1-percentage-point change in either inflation or unemployment. (This interpretation clearly depends on the cardinal scale of the dependent variable.)

The first-step regression is then

$$
\begin{aligned}
& Y_{i j}=\beta_{0}+\beta_{j}+\beta_{1} \text { Male }_{i j}+\beta_{2} \text { Age }_{i j} \\
& +\beta_{3} \text { Age }^{2}{ }_{i j}+u_{i j},
\end{aligned}
$$

where $i$ indexes individual respondents and $j$ indexes countries. We control for country fixed effects, $\beta_{j}{ }^{5}$

We define the unexplained part of dependent variable $Y$ for each country $j$ in regression (1) as the estimated fixed effect $\hat{\beta}_{j}{ }^{6}$ We then run the following regression at the country level in the second step:

$$
\begin{aligned}
& \hat{\beta}_{j}=\alpha_{0}+\alpha_{1} \text { Inflation }_{j} \\
& +\alpha_{2} \text { Unemployment }_{j}+v_{j}
\end{aligned}
$$

The second approach, which we undertake

\footnotetext{
4 Di Tella, MacCulloch, and Oswald (2001) also used an OLS regression in the first stage. They report that an ordered probit model in the first stage yields similar conclusions, but it would require redefining the unexplained dependent variable used in the second stage. Our estimated second-stage coefficients are, therefore, comparable with theirs.

5 Introducing country fixed effects is necessary to account for any country-level bias-for example, bias from focusing illusion, which results when a respondent's relative position with respect to respondents from other countries affects his or her assessment of life satisfaction (Krueger, 2008).

${ }^{6}$ In our data, this turns out to be indistinguishable from averaging the combined residual, $\hat{\beta}_{j}+\hat{u}_{i j}$, for each country $j$.
}

for comparison, consists of running a unique regression with variables measured both at the individual and at the country level. The basic estimation model is as follows:

$$
\begin{aligned}
& Y_{i j}=\beta_{0}+\beta_{1} \text { Male }_{i j}+\beta_{2} \text { Age }_{i j}+\beta_{3} \text { Age }^{2} \\
& +\alpha_{1} \text { Inflation }_{j}+\alpha_{2} \text { Unemployment }_{j}+u_{i j}
\end{aligned}
$$

Because this last regression already includes inflation and unemployment (which do not vary for individuals within a given country), we cannot include country fixed effects. In this approach, we also cluster the standard errors by country. For a robustness check, the appendix presents the results for these two approaches using a larger number of individual controls.

\section{RESULTS}

\section{Summary Statistics}

Table 1 presents the summary statistics of the measures of personal and country well-being used in our analysis. A one-way analysis of variance illustrates that although most of the variation is within countries (ranging between 70 and 90 percent of the entire variation, as represented by the total sum of squares), there is a sizable variation between countries. The averages of the wellbeing measures are better illustrated in Figure 1. The solid line represents the averages for past, present, and future personal assessments of life satisfaction. The dotted line represents the assessments for the country's situation. Three patterns are worth noting.

First, the line corresponding to personal evaluations is always above the line corresponding to the assessments of the country's situation. In other words, individuals tend to assess their personal situation as better than that of their country. We interpret the systematic differences between personal and country evaluations as a manifestation of the better-than-average effect discussed previously. The size of this effect is not small: The differences between individual life satisfaction and country situation range between 8 and 13 percent. As shown in Table 2, the differences are statistically significant, as evidenced by a standard $t$-test of differences in means. 


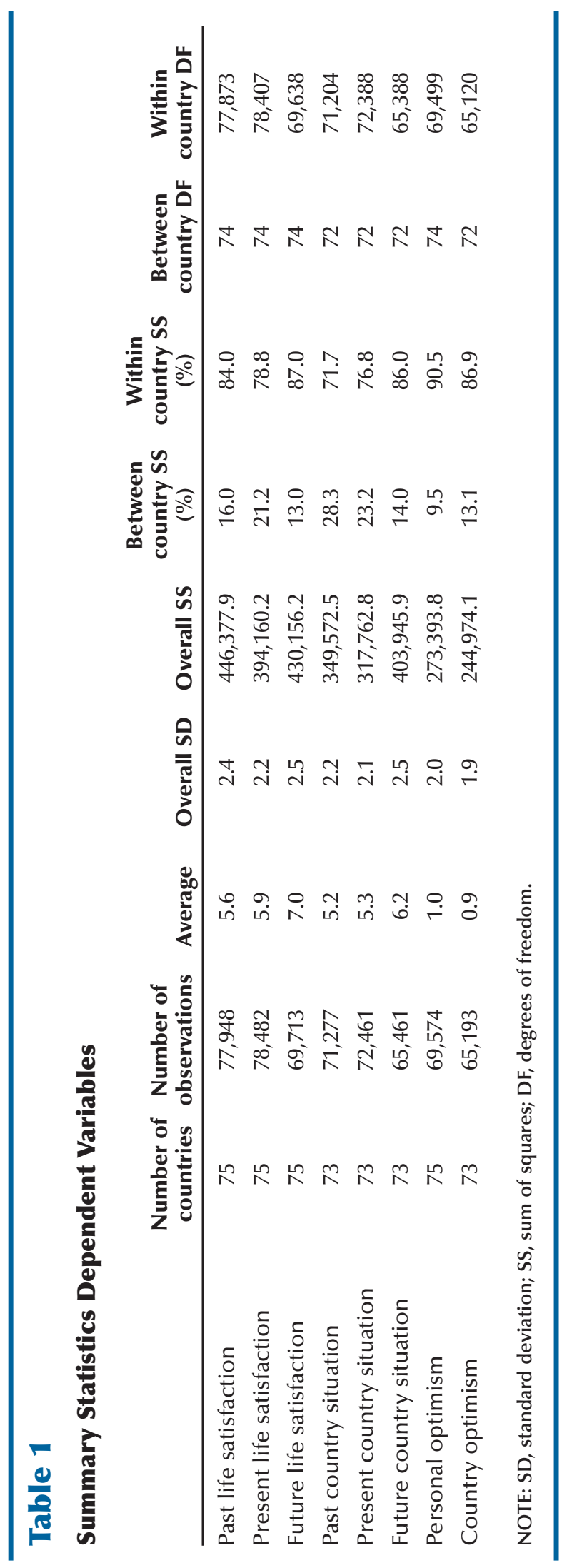




\section{Figure 1}

\section{Happiness Reports}

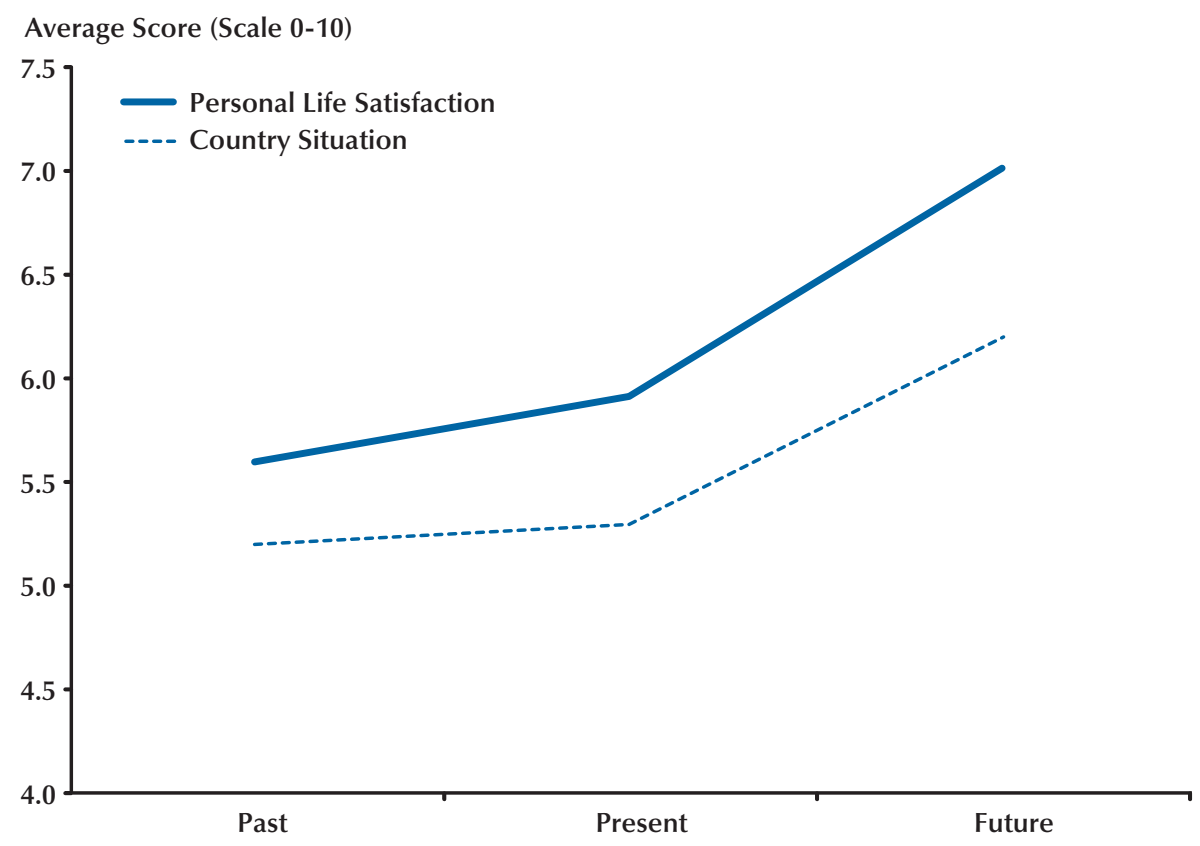

Second, there is a temporal tendency of improvements in both the assessments of personal and country well-being, as illustrated by the upward slope of both reports in Figure 1. Individual assessments of the future are better than assessments of the present, and assessments of the present are better than assessments of the past. We interpret these patterns as suggesting optimism in the well-being reports. As shown in Table 2, both personal and country measures of optimism that compare future and present assessments are also statistically significant.

Third, the rate of change between future and present and between present and past evaluations is larger in the personal assessments than in the country assessments. This indicates that people expect their personal well-being, on average, to improve more than the country's well-being will, again suggesting the presence of the better-thanaverage effect. Table 2 indicates that the differences between personal and country optimism (defined as comparing future and present assessments) are also statistically significant.
Table 3 reports summary statistics for the two macroeconomic variables studied in this paper. Data availability for these two variables determined the 75 countries that could be included in our estimations. ${ }^{7}$ To mitigate year-to-year variation, inflation and unemployment measures were computed as the average between 2004 and 2005. We also computed the lags of inflation and unemployment as the average between 2002 and 2003 to check the robustness of our estimations.

Table 4 portrays the mean and standard deviation for the individual control variables. "Male" is a dummy variable taking the value 1 for males and 0 for females. In our database, 43.9 percent of respondents are males. "Age" is measured in years; the average age is 42.5 years. "Married" is a dummy variable taking the value 1 for married people and 0 otherwise. "Employed" is a dummy

7 The World Development Indicators database contained missing values of the unemployment variable for some countries for some isolated years. These values were imputed using data for 1990-2005 with a switching regression technique. 
Table 2

t-Tests for Equality of Means of Personal and Country Assessments

\begin{tabular}{|c|c|c|c|c|}
\hline & $t$-test & $\begin{array}{c}\text { Two-sided } \\
p \text {-value }\end{array}$ & $\begin{array}{l}\text { Upper one-sided } \\
p \text {-value }\end{array}$ & Sample size \\
\hline \multicolumn{5}{|c|}{ Differences between personal and country } \\
\hline Past & 50.69 & 0.0000 & 0.0000 & 70,471 \\
\hline Present & 78.43 & 0.0000 & 0.0000 & 71,935 \\
\hline Future & 70.68 & 0.0000 & 0.0000 & 60,287 \\
\hline \multicolumn{5}{|c|}{ Differences between future and present } \\
\hline Personal optimism & 132.83 & 0.0000 & 0.0000 & 69,574 \\
\hline Country optimsim & 112.26 & 0.0000 & 0.0000 & 65,193 \\
\hline \multicolumn{5}{|l|}{ Differences in optimism } \\
\hline Personal minus country & 10.12 & 0.0000 & 0.0000 & 60,007 \\
\hline
\end{tabular}

NOTE: The above $t$-tests correspond to paired tests assuming equal variances. However, similar conclusions are reached if we allow for unequal variances.

\section{Table 3}

Summary Statistics Inflation and Unemployment

\begin{tabular}{lccccc} 
& Average (\%) & SD (\%) & Minimum (\%) & Maximum (\%) & $\begin{array}{c}\text { Number of } \\
\text { observations }\end{array}$ \\
\hline Inflation & 5.0 & 4.6 & -0.1 & 27.8 & 75 \\
Unemployment & 9.1 & 5.5 & 1.4 & 37.3 & 75 \\
Lag inflation & 5.3 & 6.3 & -2.8 & 35.1 & 75 \\
Lag unemployment & 9.6 & 5.9 & 1.7 & 34.3 & 75
\end{tabular}

NOTE: Inflation and unemployment are computed as the average for the period 2004-05. Lagged inflation and unemployment correspond to the averages for 2002-03. SD is standard deviation.

variable taking the value 1 when the individual has a job (whether paid or unpaid) and 0 otherwise. "Urban" is a dummy variable taking the value 1 for individuals living in cities and 0 if they live in a rural area. Finally, we include a dummy variable (labeled "Poor") that takes the value 1 if the individual has an income of at most two U.S. dollars per day and 0 otherwise. The analysis of variance reveals, as in Table 1, that most of the variation corresponds to within-country variation.

\section{Regression Analysis}

Table 5 reports the results of the two-stage approach. The top panel presents the first-stage regression of the personal and country evaluations on only individual controls, accounting for country fixed effects. The middle and bottom panels present the second-stage regression illustrating the impact of inflation and unemployment (current and lagged values, respectively) on the country averages of personal and country evaluations that are not explained by individual controls. Tables 6 and 7 report the results of the second approach of a single regression of the well-being measures on individual controls and the macro variables.

Both estimation strategies yield similar results. At the individual level, males tend to be 


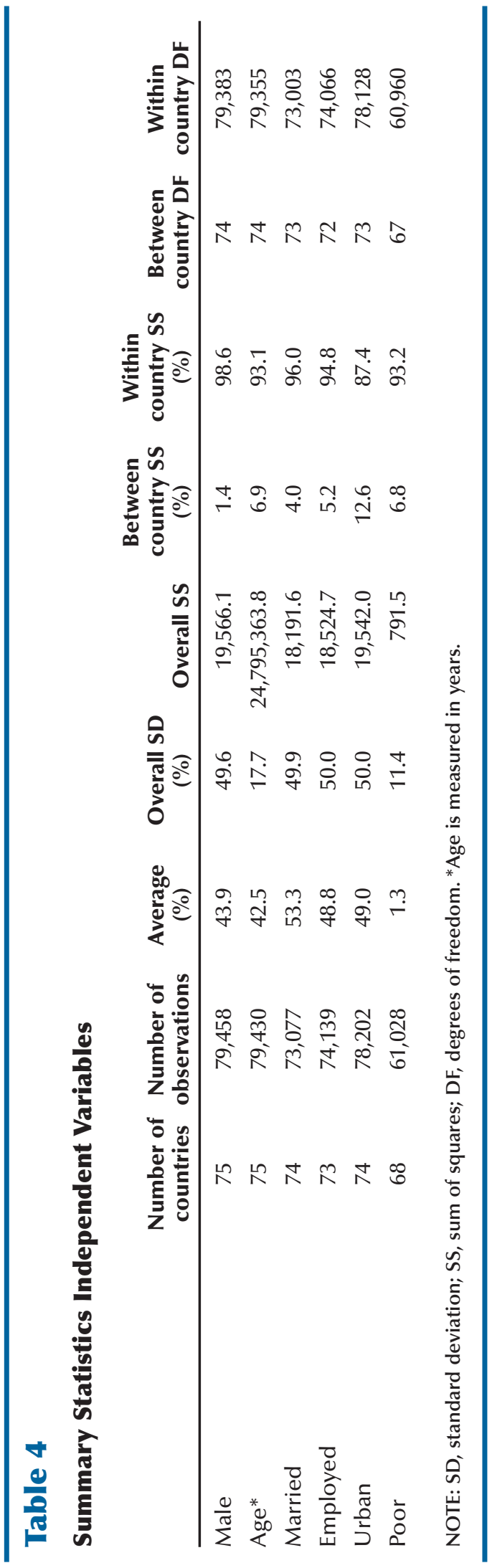


Table 5

Results of the Two-Stage Approach

\begin{tabular}{|c|c|c|c|c|c|c|c|c|}
\hline & \multicolumn{4}{|c|}{ Life satisfaction } & \multicolumn{4}{|c|}{ Country situation } \\
\hline & Present & Past & Future & Future-Present & Present & Past & Future & Future-Present \\
\hline \multicolumn{9}{|l|}{ First stage } \\
\hline Male & $\begin{array}{l}-0.09041^{* * *} \\
(-4.01)\end{array}$ & $\begin{array}{l}-0.01379 \\
(-0.56)\end{array}$ & $\begin{array}{l}-0.11673^{* * *} \\
(-4.68)\end{array}$ & * $\begin{array}{l}-0.01955 \\
(-1.28)\end{array}$ & $\begin{array}{l}-0.01411 \\
(-0.57)\end{array}$ & $\begin{array}{l}-0.10445^{* * *} \\
(-5.53)\end{array}$ & $\begin{array}{l}-0.05914^{*} \\
(-1.80)\end{array}$ & $\begin{array}{l}-0.03783^{*} \\
(-1.99)\end{array}$ \\
\hline Age & $\begin{array}{l}-0.03095^{* * *} \\
(-7.28)\end{array}$ & $\begin{array}{l}-0.02204^{* * *} \\
(-6.09)\end{array}$ & $\begin{array}{l}* 0.03609 * * * \\
(-5.16)\end{array}$ & $\begin{array}{l}-0.00911^{* *} \\
(-2.08)\end{array}$ & $\begin{array}{l}-0.01642^{* * *} \\
(-5.62)\end{array}$ & $\begin{array}{l}-0.00308 \\
(-0.94)\end{array}$ & $\begin{array}{l}-0.03344^{* * *} \\
(-8.93)\end{array}$ & * $\begin{aligned}-0.01815^{* * *} \\
(-8.14)\end{aligned}$ \\
\hline $\mathrm{Age}^{2}$ & $\begin{array}{l}0.00019 * * * \\
(4.16)\end{array}$ & $\begin{array}{l}0.00028^{* * *} \\
(6.5)\end{array}$ & $\begin{array}{l}* 0.00003 \\
(-0.43)\end{array}$ & $\begin{array}{l}-0.00018^{* * *} \\
(-3.78)\end{array}$ & $\begin{array}{l}0.00015^{* * *} \\
(5.27)\end{array}$ & $\begin{array}{l}0.00007^{* *} \\
(2.06)\end{array}$ & $\begin{array}{l}0.00029^{* * *} \\
(7.46)\end{array}$ & $\begin{array}{l}0.00014^{* * *} \\
(5.58)\end{array}$ \\
\hline Constant & $\begin{array}{l}\text { 6.88610*** } \\
(71.2)\end{array}$ & $\begin{array}{l}5.94741^{* * *} \\
(74.59)\end{array}$ & $\begin{array}{l}*{ }^{*} .60801^{* * *} \\
(55.83)\end{array}$ & $\begin{array}{l}* \quad 1.76106^{* * *} \\
(19.9)\end{array}$ & $\begin{array}{l}5.71184^{* * *} \\
(80.59)\end{array}$ & $\begin{array}{l}5.23426^{* * *} \\
(71.13)\end{array}$ & $\begin{array}{l}\text { * } 7.06410^{* * *} \\
(82.6)\end{array}$ & $\begin{array}{l}* \quad 1.33646 * * * \\
(27.11)\end{array}$ \\
\hline Country dummies & Yes & Yes & Yes & Yes & Yes & Yes & Yes & Yes \\
\hline$N$ & 78,449 & 77,914 & 69,679 & 69,541 & 72,429 & 71,245 & 65,429 & 65,161 \\
\hline$R^{2}$ & 0.016 & 0.002 & 0.079 & 0.053 & 0.002 & 0.002 & 0.005 & 0.003 \\
\hline$R^{2(*)}$ & 0.22417 & 0.16168 & 0.19857 & 0.14271 & 0.23345 & 0.28479 & 0.14394 & 0.13403 \\
\hline \multicolumn{9}{|c|}{ Second stage: current variables } \\
\hline Inflation & $\begin{array}{l}-0.06536^{* *} \\
(-2.09)\end{array}$ & $\begin{array}{l}-0.06496^{* *} \\
(-2.47)\end{array}$ & $\begin{array}{l}-0.01729 \\
(-0.58)\end{array}$ & $\begin{array}{l}0.04615^{* * *} \\
(4.01)\end{array}$ & $\begin{array}{l}-0.05685^{*} \\
(-1.90)\end{array}$ & $\begin{array}{l}-0.09574^{* * *} \\
(-3.07)\end{array}$ & $\begin{array}{l}0.00034 \\
(0.01)\end{array}$ & $\begin{array}{l}0.05619 * * * \\
(4.72)\end{array}$ \\
\hline Unemployment & $\begin{array}{l}-0.05961^{* * *} \\
(-5.15)\end{array}$ & $\begin{array}{l}-0.04201^{* * *} \\
(-3.55)\end{array}$ & $\begin{array}{l}-0.04075^{* * *} \\
(-3.44)\end{array}$ & $\begin{array}{l}0.01761^{* *} \\
(2.19)\end{array}$ & $\begin{array}{l}-0.05420^{* * *} \\
(-2.90)\end{array}$ & $\begin{array}{l}-0.06799 * * * \\
(-3.80)\end{array}$ & $\begin{array}{l}-0.01501 \\
(-0.70)\end{array}$ & $\begin{array}{l}0.03839^{* * *} \\
(3.86)\end{array}$ \\
\hline No. of countries & 75 & 75 & 75 & 75 & 73 & 73 & 73 & 73 \\
\hline$R^{2}$ & 0.218 & 0.208 & 0.077 & 0.21 & 0.186 & 0.298 & 0.008 & 0.28 \\
\hline $\begin{array}{l}\text { F-test for inflation }= \\
\text { unemployment }\end{array}$ & 0.03668 & 0.68952 & 0.62259 & 3.33055 & 0.00611 & 0.64291 & 0.17494 & 1.07965 \\
\hline$p$-Value & 0.84866 & 0.40907 & 0.43268 & 0.07215 & 0.93793 & 0.42537 & 0.67704 & 0.30235 \\
\hline \multicolumn{9}{|c|}{ Second stage: lag variables } \\
\hline Lag inflation & $\begin{array}{l}-0.02683 \\
(-1.36)\end{array}$ & $\begin{array}{l}-0.02243 \\
(-1.59)\end{array}$ & $\begin{array}{l}-0.00944 \\
(-0.45)\end{array}$ & $\begin{array}{l}0.01660^{*} \\
(1.68)\end{array}$ & $\begin{array}{l}-0.02508 \\
(-1.54)\end{array}$ & $\begin{array}{l}-0.05527^{* * *} \\
(-3.80)\end{array}$ & $\begin{array}{l}0.00815 \\
(0.47)\end{array}$ & $\begin{array}{l}0.03298^{* * *} \\
(3.55)\end{array}$ \\
\hline Lag unemployment & $\begin{array}{l}-0.06220^{* * *} \\
(-4.59)\end{array}$ & $\begin{array}{l}-0.04651^{* * *} \\
(-3.62)\end{array}$ & $\begin{array}{l}-0.03883^{* * *} \\
(-2.80)\end{array}$ & $\begin{array}{l}0.02215^{* *} \\
(2.45)\end{array}$ & $\begin{array}{l}-0.05398^{* *} \\
(-2.61)\end{array}$ & $\begin{array}{l}-0.07139 * * * \\
(-3.28)\end{array}$ & $\begin{array}{l}-0.01211 \\
(-0.59)\end{array}$ & $\begin{array}{l}0.04104^{* * *} \\
(3.91)\end{array}$ \\
\hline No. of countries & 75 & 75 & 75 & 75 & 73 & 73 & 73 & 73 \\
\hline$R^{2}$ & 0.173 & 0.135 & 0.074 & 0.113 & 0.145 & 0.267 & 0.007 & 0.257 \\
\hline $\begin{array}{l}\text { F-test for inflation }= \\
\text { unemployment }\end{array}$ & 2.2978 & 1.52646 & 1.21838 & 0.14166 & 1.069 & 0.34143 & 0.46129 & 0.27637 \\
\hline$p$-Value & 0.13394 & 0.22066 & 0.27335 & 0.70774 & 0.30473 & 0.56088 & 0.49926 & 0.60075 \\
\hline
\end{tabular}

NOTE: $t$-Statistics are in parentheses. $R^{2}$ corresponds to the between model. $R^{2(*)}$ accounts for the variation explained by the fixed effects. ${ }^{*} p<0.1,{ }^{* *} p<0.05,{ }^{* * *} p<0.01$. 


\section{Table 6}

\section{Results of the Single-Stage Approach: Current Inflation and Unemployment}

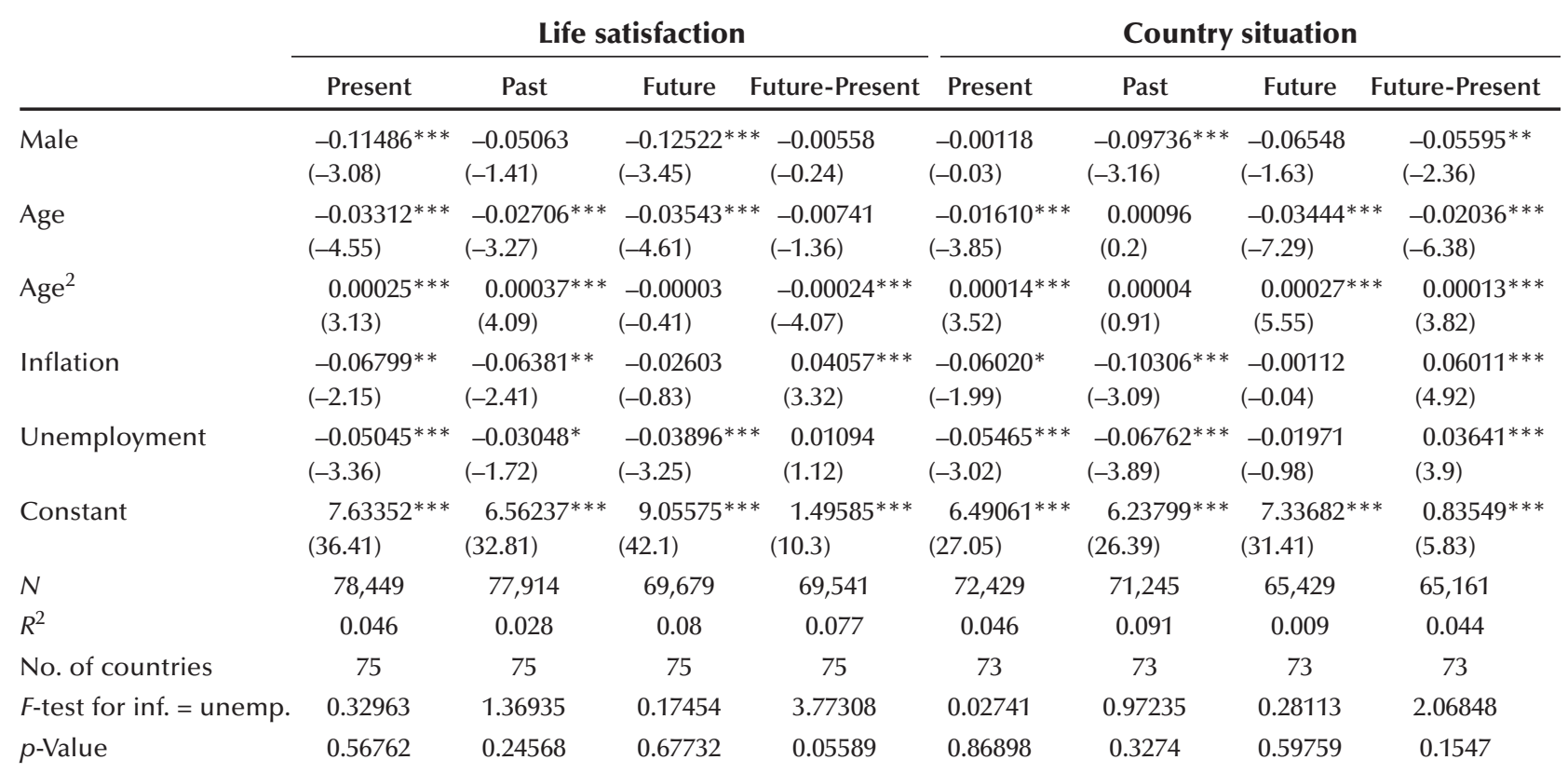

NOTE: $t$-Statistics are in parentheses. $R^{2}$ corresponds to the between model. ${ }^{*} p<0.1,{ }^{* *} p<0.05,{ }^{* * *} p<0.01$.

Table 7

Results of the Single-Stage Approach: Lag Inflation and Unemployment

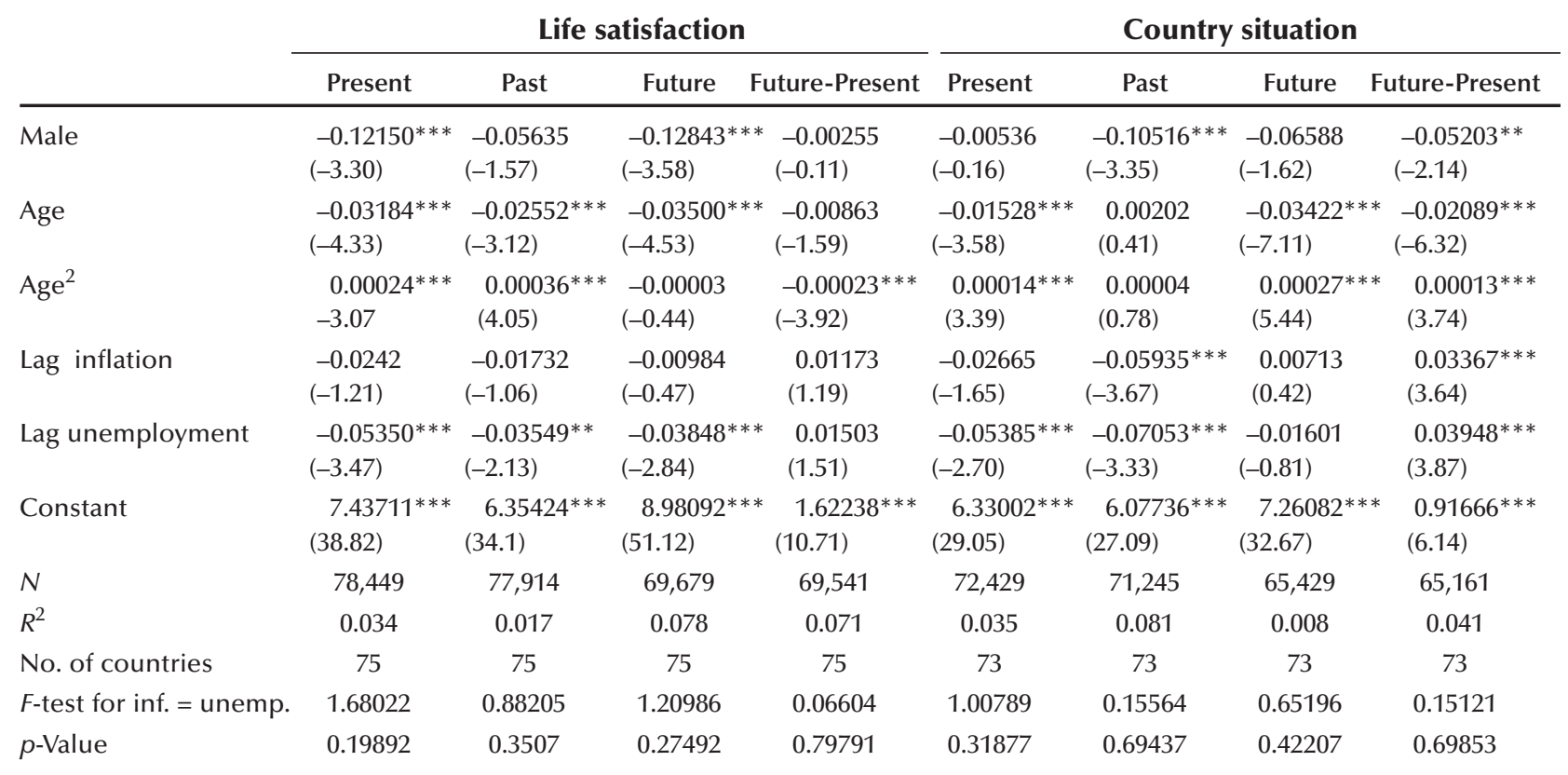

NOTE: $t$-Statistics are in parentheses. $R^{2}$ corresponds to the between model. ${ }^{*} p<0.1,{ }^{* *} p<0.05,{ }^{* * *} p<0.01$. 
more critical of their current situation and their expectations about the future (as indicated by a negative and statistically significant coefficient of the "Male" variable on the respective regressions). Males also tend to be more critical of the past situation of the country, but we find no significant gender-based appreciation differences for the current assessment of country well-being. Males also tend to be less optimistic with respect to the country's future well-being; this can be seen in the significant negative coefficient in the future country well-being regression in Table 5 and in the negative significant coefficient for the expected country improvements (future-present) in Tables 5, 6, and 7.

In general we find that both age (measured in years) and its square are significant determinants of personal and country subjective evaluations, but there are quantitative differences of their effects on the different well-being measures, especially between the assessment for present and past well-being. The nonlinear nature of the estimated relationship with age implies that personal and country (past, present, and future) evaluations tend to decrease with age until a turning point in which the marginal effect of an additional year yields an improvement in the subjective evaluation. Di Tella, MacCulloch, and Oswald (2001) also find a negative sign on age and a small positive sign on age squared in their analysis of personal life satisfaction.

According to Table 5, the present life satisfaction is a decreasing function of age up to 81 years. The turning point for past life satisfaction is at 40 years. This may reflect a tendency of older people to better evaluate the past. Tables 6 and 7 present similar results. The age turning point in the life satisfaction regression is about 66 years, but in the regression for the past personal situation the turning point is about 37 years.

We have defined the measure of optimism as the change between the future and present situation (both with respect to the individual and country situation), and we interpret this variable as illustrating expectations about future improvements in one's own life satisfaction or future improvements in one's perceptions of the country's situation. The results indicate that the impact of age on future evaluation is more negative than in the evaluation of the past and present. According to Table 5, the turning point on future personal evaluation is above normal age spans (133 years), but the coefficient on age squared is not statistically significant. However, the regression of the personal optimism regarding life satisfaction (i.e., improvements in personal evaluation of life satisfaction) exhibits a significant negative agesquared term. This means that not only an additional year of life makes people believe that things will be worse for them in the future but also that the marginal effect of this additional year grows with age in absolute value, as life satisfaction optimism declines at increasing rates with age.

Tables A2, A3, and A4 (see appendix) reproduce the two estimation approaches with a wider set of individual explanatory variables. In line with previous research (see, for example, Di Tella, MacCulloch, and Oswald, 2001), we find that married people tend to report higher personal life satisfaction than nonmarried people. However, according to the results reported in the appendix, the impact of marriage status on the country evaluations is not robust to the estimation strategy. We also find that employed people tend to report higher assessments of personal and country wellbeing than unemployed people, but their assessment for the future both with respect to the individual and country situation is lower than for unemployed individuals. People living in urban centers tend to show higher individual assessment of life satisfaction than people living in rural areas, but we find no significant differential effect for the assessments of country well-being. Finally, as expected, poor people tend to assess their current, past, and future well-being as being worse than richer people, as is the case for their assessment of the country's current well-being. More interesting, poorer people expect their well-being to improve in the future more than richer people do, as implied by the positive coefficient in the optimism regressions. 


\section{EFFECTS OF INFLATION AND UNEMPLOYMENT ON LIFE SATISFACTION}

Both estimation strategies (and using both sets of individual controls) report a very consistent set of results. We find that an individual's present and past assessments of personal well-being tend to be negatively affected by the country's inflation and unemployment levels. The expectations about future personal well-being are not affected by the level of inflation but are negatively affected by the level of unemployment. An individual's assessment of the country's present and past wellbeing is also negatively affected by current inflation and unemployment, but not the assessment of the country's future well-being.

With respect to the effects on optimism about personal satisfaction and the country's well-being, we find that individuals' optimism measures tend to respond positively to current inflation and unemployment. Rather than interpreting this result as inflation and unemployment having a boosting effect on optimism, we believe that these macroeconomic variables depress the evaluation of the present relative to the evaluation of the future. In other words, higher current inflation or unemployment creates the effect of improved optimism, not because the future is assessed as more favorable but because individuals believe the present looks grimmer.

The regression using lagged inflation and lagged unemployment values shows significant effects on the assessment of personal optimism only from unemployment in the two-stage approach (Table 5), but not in the single-stage approach (Table 7). Both inflation and unemployment seem to have an effect on the assessments of country optimism using either approach.

Finally, in contrast with previous studies, we did not find statistically significant differences in the coefficients for inflation and unemployment for most of the regression specifications in our analysis, as indicated by the insignificant Wald $F$-statistics in the tables in a test of equality of the coefficients for inflation and unemployment. This difference from other studies may be attrib- uted to two important factors. First, we analyze a set of countries from several world regions that exhibit widely different patterns of inflation and unemployment, while previous studies analyze countries that often belong to more homogeneous regions or income groups. Second, although most other studies analyze a reduced number of countries, they also have data for several years, whereas we have data only for 2006 .

\section{CONCLUSION}

In this study, we used Gallup World Poll data to analyze the determinants of individual assessments of personal and country well-being. With these data we extended the number of countries in the analysis beyond those of other studies in the literature.

Using individual assessments of past, present, and future measures of personal and country wellbeing, we examine two dimensions of happiness data that have not been previously analyzed in the literature. (i) By comparing the assessments for personal and country well-being we found evidence of the better-than-average effect identified in the overconfidence literature. (ii) By comparing future and present evaluations we also found evidence of optimism in the assessments of well-being.

We also analyzed the effects of inflation and unemployment on eight subjective measures of well-being (past, present, and future assessment of personal and country well-being, and personal and country optimism). We found that both inflation and unemployment have a negative effect on individuals' assessments of personal and country past and present well-being. We also found a positive impact of inflation and unemployment on the optimism measures because both inflation and unemployment worsen the evaluations of present well-being relative to the future. Our results suggest that policymakers designing measures targeted at reducing the perceived costs of inflation and unemployment may consider exploiting the differential effect of these macroeconomic variables on expectations of future well-being relative to current well-being. 


\section{REFERENCES}

Benoît, Jean-Pierre; Dubra, Juan and Moore, Don. "Does the Better-Than-Average Effect Show That People Are Overconfident? An Experiment." Munich Personal RePEc Archive Paper No. 13168, February 2009; http://mpra.ub.uni-muenchen.de/ 13168/1/MPRA_paper_13168.pdf.

Benoît, Jean-Pierre and Dubra, Juan. “Overconfidence?" January 2009; available at http://ssrn.com/abstract=1088746.

Blanchflower, David. "Is Unemployment More Costly than Inflation?” NBER Working Paper No. 13505, National Bureau of Economic Research, October 2007; www.nber.org/papers/w13505.pdf?new_ window $=1$.

Blanchflower, David and Oswald, Andrew J. "WellBeing over Time in Britain and the United States." Journal of Public Economics, July 2004, 88(7-8), pp. 1359-86.

Caliendo, Frank and Huang, Kevin X.D. "Overconfidence and Consumption over the Life Cycle." Unpublished manuscript, Vanderbilt University, August 2007.

Camerer, Colin and Lovallo, Dan. "Overconfidence and Excess Entry: An Experimental Approach.” American Economic Review, March 1999, 89(1), pp. 306-18.

Chuang, Wen-I and Lee, Bong-Soo. "An Empirical Evaluation of the Overconfidence Hypothesis." Journal of Banking and Finance, September 2006, 30(9), pp. 2489-515.

Clark, Andrew E. and Oswald, Andrew J. "Unhappiness and Unemployment." Economic Journal, May 1994, 104(424), pp. 648-59.

Deaton, Angus. "Income, Aging, Health and WellBeing Around the World: Evidence from the Gallup World Poll." Journal of Economic Perspectives, Spring 2008, 22(2), pp. 53-72.

Di Tella, Rafael; MacCulloch, Robert J. and Oswald, Andrew J. "Preferences over Inflation and Unemployment: Evidence from Surveys of
Happiness." American Economic Review, March 2001, 91(1), pp. 335-41.

Di Tella, Rafael; MacCulloch, Robert J. and Oswald, Andrew J. "The Macroeconomics of Happiness." Review of Economics and Statistics, November 2003, 85(4), pp. 809-27.

Di Tella, Rafael and MacCulloch, Robert J. "Some Uses of Happiness Data in Economics." Journal of Economic Perspectives, Winter 2006, 20(1), pp. 25-46.

Easterlin, Richard. "Does Economic Growth Improve the Human Lot? Some Empirical Evidence," in Paul A. David and M.W. Reder, eds., Nations and Households in Economic Growth: Essays in Honour of Moses Abramovitz. London: Academic Press, 1974, pp. 98-125.

Easterlin, Richard. "Will Raising the Incomes of All Increase the Happiness of All?" Journal of Economic Behavior and Organization, June 1995, 27(1), pp. 35-48.

Easterly, William and Fischer, Stanley. "Inflation and the Poor." Journal of Money, Credit, and Banking, May 2001, 33(2), pp. 160-78.

Frey, Bruno and Stutzer, Alois. "What Can Economists Learn from Happiness Research?" Journal of Economic Literature, June 2002, 40(2), pp. 402-35.

Jayadev, Arjun. "The Class Content of Preferences Towards Anti-Inflation and Anti-Unemployment Policies." International Review of Applied Economics, March 2008, 22(2), pp. 161-72.

Krueger, Alan. "Comment on Stevenson and Wolfers." Brookings Papers on Economic Activity, Spring 2008, 2, pp. 95-100.

Lora, Eduardo. Beyond Facts. Understanding Quality of Life, Inter-American Development Bank. Cambridge, MA: Harvard University Press, 2008.

Lovell, Michael C. and Tien, Pao-Lin. "Economic Discomfort and Consumer Sentiment.” Eastern Economic Journal, Winter 2000, 26(1), pp. 1-8.

Peiró, Amado. "Happiness, Satisfaction and Socioeconomic Conditions: Some International 
Evidence." Journal of Socio-Economics, April 2006, 35(2), pp. 348-65.

Scoppa, Vincenzo and Ponzo, Michela. "An Empirical Study of Happiness in Italy." B.E. Journal of

Economic Analysis \& Policy, 2008, 8(1), Article 15.

Stevenson, Betsey and Wolfers, Justin. "Economic Growth and Subjective Well-Being: Reassessing the Easterlin Paradox." Brookings Papers on Economic Activity, Spring 2008, 2, pp. 1-87.

van Praag, Bernard, M.S.; Frijters, Paul and Ferrer-iCarbonell, Ada. "The Anatomy of Subjective Well-Being." Journal of Economic Behavior and Organization, May 2003, 51(1), pp. 23-49.

Veenhoven, Ruut. Happiness in Nations: Subjective Appreciation of Life in 56 Nations, 1946-1992. Rotterdam: Erasmus University Press, 1993.

Wolfers, Justin. "Is Business Cycle Volatility Costly? Evidence from Surveys of Subjective Well-Being." International Finance, Spring 2003, 6(1), pp. 1-26.

The World Bank Group. World Development Indicators Online 2007. Washington, DC, 2007. 


\section{APPENDIX}

\section{Table A1}

\section{List of Countries Used in the Analysis}

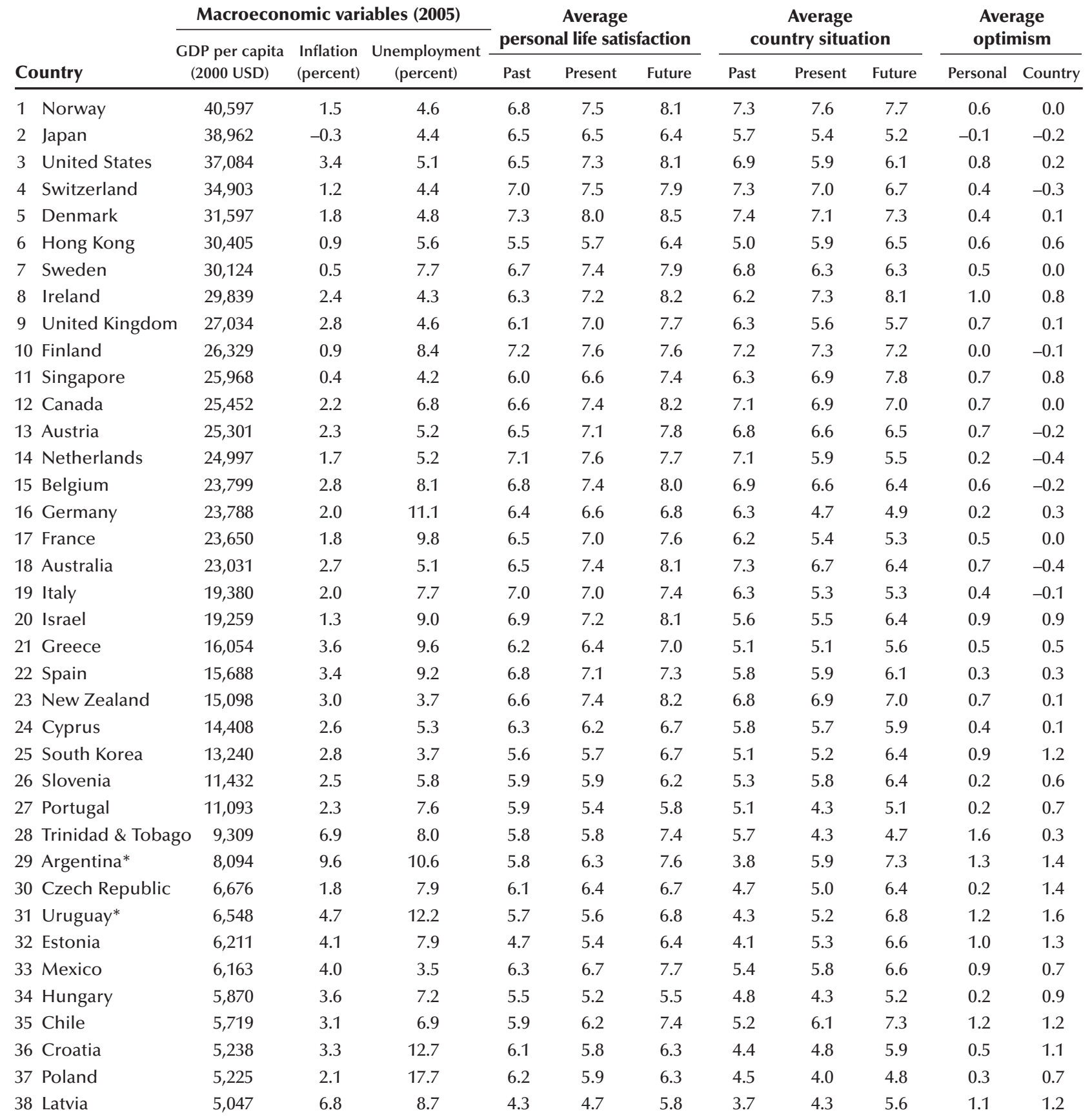

NOTE: *Indicates country with a missing value for the unemployment rate over the 2002-05 period in the 2007 World Development Indicators database. Missing data were imputed. 


\section{Table A1, cont'd}

\section{List of Countries Used in the Analysis}

\begin{tabular}{|c|c|c|c|c|c|c|c|c|c|c|c|}
\hline \multirow[b]{3}{*}{ Country } & \multicolumn{3}{|c|}{ Macroeconomic variables (2005) } & \multirow{2}{*}{\multicolumn{3}{|c|}{$\begin{array}{c}\text { Average } \\
\text { personal life satisfaction }\end{array}$}} & \multirow{2}{*}{\multicolumn{3}{|c|}{$\begin{array}{c}\text { Average } \\
\text { country situation }\end{array}$}} & \multirow{2}{*}{\multicolumn{2}{|c|}{$\begin{array}{c}\text { Average } \\
\text { optimism }\end{array}$}} \\
\hline & \multirow{2}{*}{$\begin{array}{l}\text { GDP per capita } \\
\text { (2000 USD) }\end{array}$} & \multirow{2}{*}{$\begin{array}{l}\text { Inflation } \\
\text { (percent) }\end{array}$} & \multirow{2}{*}{$\begin{array}{l}\text { Unemployment } \\
\text { (percent) }\end{array}$} & & & & & & & & \\
\hline & & & & Past & Present & Future & Past & Present & Future & Personal & Country \\
\hline 39 Venezuela* & 5,001 & 16.0 & 16.8 & 6.2 & 7.2 & 8.5 & 4.9 & 5.8 & 7.6 & 1.2 & 1.7 \\
\hline 40 Lithuania & 4,873 & 2.7 & 8.3 & 5.6 & 5.9 & 6.7 & 4.5 & 4.7 & 6.1 & 0.7 & 1.3 \\
\hline 41 Slovakia & 4,733 & 2.7 & 16.2 & 5.2 & 5.2 & 5.6 & 4.1 & 4.2 & 5.2 & 0.4 & 0.9 \\
\hline 42 Costa Rica & 4,505 & 13.8 & 6.6 & 6.8 & 7.0 & 7.7 & 6.2 & 5.7 & 6.0 & 0.6 & 0.4 \\
\hline 43 Panama & 4,429 & 3.3 & 10.3 & 5.6 & 6.2 & 8.1 & 4.8 & 5.4 & 7.2 & 1.9 & 1.8 \\
\hline 44 Botswana* & 4,382 & 8.6 & 23.8 & 4.1 & 4.6 & 6.5 & 5.3 & 5.8 & 6.9 & 1.9 & 1.2 \\
\hline 45 Malaysia* & 4,360 & 3.0 & 3.0 & 5.2 & 6.1 & 7.6 & 5.5 & 6.4 & 7.6 & 1.5 & 1.3 \\
\hline 46 Brazil* & 3,951 & 6.9 & 9.7 & 5.7 & 6.5 & 8.6 & 5.2 & 4.9 & 7.0 & 2.1 & 2.0 \\
\hline 47 South Africa & 3,429 & 3.4 & 26.7 & 5.2 & 5.4 & 7.0 & 5.4 & 5.6 & 7.0 & 1.5 & 1.4 \\
\hline 48 Turkey & 3,425 & 10.1 & 10.3 & 4.5 & 4.7 & 5.8 & 3.7 & 4.6 & 5.9 & 1.1 & 1.3 \\
\hline 49 Jamaica & 3,291 & 15.3 & 10.9 & 5.2 & 6.2 & 8.3 & 4.5 & 4.9 & 5.7 & 2.0 & 0.9 \\
\hline 50 Thailand & 2,494 & 4.5 & 1.3 & 5.6 & 6.0 & 7.4 & 6.0 & 5.4 & 6.8 & 1.3 & 1.3 \\
\hline 51 Dominican Rep. & 2,471 & 4.2 & 17.9 & 4.9 & 5.1 & 7.7 & 3.9 & 5.0 & 7.3 & 2.5 & 2.2 \\
\hline 52 Russia* & 2,444 & 12.7 & 8.1 & 4.7 & 5.0 & 6.2 & 3.6 & 4.7 & 6.1 & 1.1 & 1.3 \\
\hline 53 Peru & 2,396 & 1.6 & 11.4 & 4.7 & 4.9 & 6.8 & 4.4 & 4.1 & 5.8 & 1.7 & 1.6 \\
\hline 54 Romania & 2,259 & 9.0 & 7.2 & 5.6 & 5.3 & 5.9 & 4.1 & 3.8 & 5.2 & 0.5 & 1.4 \\
\hline 55 El Salvador* & 2,202 & 4.7 & 7.4 & 5.8 & 5.6 & 5.5 & 5.3 & 4.7 & 4.1 & -0.2 & -0.4 \\
\hline 56 Colombia & 2,199 & 5.0 & 9.5 & 5.6 & 5.9 & 7.9 & 4.5 & 5.2 & 6.9 & 1.9 & 1.6 \\
\hline 57 Bulgaria & 2,107 & 5.0 & 10.1 & 4.0 & 3.8 & 5.0 & 3.1 & 3.3 & 5.0 & 1.1 & 1.7 \\
\hline 58 Jordan* & 2,104 & 3.5 & 12.4 & 6.1 & 6.3 & 7.1 & 5.9 & 6.4 & 7.3 & 0.7 & 0.9 \\
\hline 59 Kazakhstan & 1,978 & 7.6 & 8.1 & 4.5 & 5.5 & 7.3 & 3.9 & 5.9 & 7.8 & 1.8 & 1.9 \\
\hline 60 Macedonia & 1,892 & 0.0 & 37.3 & 4.6 & 4.5 & 5.5 & 3.6 & 3.5 & 4.8 & 1.0 & 1.2 \\
\hline 61 Guatemala* & 1,719 & 8.4 & 3.9 & 6.0 & 6.0 & 6.9 & 5.0 & 4.8 & 5.3 & 0.8 & 0.5 \\
\hline 62 Egypt* & 1,643 & 4.9 & 10.7 & 5.2 & 5.2 & 7.0 & NA & NA & NA & 1.7 & NA \\
\hline 63 Ecuador & 1,589 & 2.4 & 7.7 & 5.3 & 5.1 & 6.3 & 4.5 & 4.0 & 5.1 & 1.1 & 1.0 \\
\hline 64 Morocco & 1,562 & 1.0 & 11.0 & 4.0 & 4.6 & 7.1 & 3.8 & 4.8 & 7.1 & 2.5 & 2.3 \\
\hline 65 China & 1,451 & 1.8 & 4.2 & 3.8 & 4.8 & 6.7 & NA & NA & NA & 1.9 & NA \\
\hline 66 Paraguay* & 1,361 & 6.8 & 7.6 & 5.6 & 4.9 & 5.2 & 4.9 & 3.7 & 4.2 & 0.4 & 0.5 \\
\hline 67 Philippines & 1,117 & 7.6 & 7.4 & 4.8 & 4.7 & 5.7 & 5.1 & 4.0 & 5.0 & 1.0 & 1.0 \\
\hline 68 Bolivia* & 1,061 & 5.4 & 4.3 & 4.9 & 5.4 & 7.0 & 3.8 & 5.0 & 6.8 & 1.7 & 1.8 \\
\hline 69 Honduras & 1,039 & 8.8 & 4.2 & 4.9 & 5.3 & 7.1 & 4.3 & 4.1 & 4.6 & 1.6 & 0.5 \\
\hline 70 Sri Lanka & 1,007 & 11.6 & 7.6 & 3.6 & 4.3 & 6.2 & 3.8 & 4.8 & 6.7 & 1.8 & 1.8 \\
\hline 71 Georgia & 974 & 8.2 & 13.8 & 3.4 & 3.6 & 5.6 & 2.4 & 3.9 & 6.2 & 1.7 & 2.2 \\
\hline 72 Ukraine & 962 & 13.5 & 7.2 & 4.8 & 4.9 & 5.8 & 3.9 & 3.9 & 4.7 & 0.8 & 0.8 \\
\hline 73 Indonesia & 942 & 10.5 & 10.3 & 5.1 & 5.0 & 6.6 & 5.4 & 4.9 & 6.4 & 1.6 & 1.5 \\
\hline 74 Pakistan & 606 & 9.1 & 7.7 & 5.0 & 6.1 & 7.4 & 4.9 & 5.2 & 6.4 & 1.3 & 1.3 \\
\hline 75 Moldova & 468 & 13.1 & 7.3 & 5.0 & 4.9 & 5.6 & 4.4 & 4.5 & 5.6 & 0.7 & 1.0 \\
\hline
\end{tabular}

NOTE: *Indicates country with a missing value for the unemployment rate over the 2002-05 period in the 2007 World Development Indicators database. Missing data were imputed. 
Table A2

Results of the Two-Stage Approach

\begin{tabular}{|c|c|c|c|c|c|c|c|c|}
\hline & \multicolumn{4}{|c|}{ Life satisfaction } & \multicolumn{4}{|c|}{ Country situation } \\
\hline & Present & Past & Future & Future-Present & Present & Past & Future & Future-Present \\
\hline \multicolumn{9}{|l|}{ First stage } \\
\hline Male & $\begin{array}{l}-0.12100^{* * *} \\
(-5.10)\end{array}$ & $\begin{array}{l}0.0212 \\
(0.88)\end{array}$ & $\begin{array}{l}-0.14417^{* * *} \\
(-4.82)\end{array}$ & $\begin{array}{l}-0.02933 \\
(-1.53)\end{array}$ & $\begin{array}{l}0.01849 \\
(0.85)\end{array}$ & $\begin{array}{l}-0.08521^{* * *} \\
(-4.20)\end{array}$ & $\begin{array}{l}-0.01069 \\
(-0.33)\end{array}$ & $\begin{array}{l}-0.02822 \\
(-1.33)\end{array}$ \\
\hline Age & $\begin{array}{l}-0.06079 \text { *** } \\
(-10.64)\end{array}$ & $\begin{array}{l}-0.02668^{* * *} \\
(-6.54)\end{array}$ & $\begin{array}{l}-0.06108^{* * *} \\
(-7.05)\end{array}$ & $\begin{array}{l}-0.00431 \\
(-0.74)\end{array}$ & $\begin{array}{l}-0.02070^{* * *} \\
(-5.15)\end{array}$ & $\begin{array}{l}-0.00329 \\
(-0.93)\end{array}$ & $\begin{array}{l}-0.03789^{* * *} \\
(-7.36)\end{array}$ & $\begin{aligned} * & -0.01743^{* * *} \\
& (-5.04)\end{aligned}$ \\
\hline $\mathrm{Age}^{2}$ & $\begin{array}{l}0.00051^{* * *} \\
(8.76)\end{array}$ & $\begin{array}{l}0.00033^{* * *} \\
(6.59)\end{array}$ & $\begin{array}{l}0.00023^{* * *} \\
(2.74)\end{array}$ & $\begin{array}{l}*-0.00024^{* * *} \\
(-3.84)\end{array}$ & $\begin{array}{l}0.00019^{* * *} \\
(4.7)\end{array}$ & $\begin{array}{l}0.00007^{*} \\
(1.92)\end{array}$ & $\begin{array}{l}0.00034^{* * *} \\
(6.21)\end{array}$ & $\begin{array}{ll}* \quad & 0.00013^{* * *} \\
& (3.66)\end{array}$ \\
\hline Married & $\begin{array}{l}0.36510^{* * *} \\
(12.66)\end{array}$ & $\begin{array}{l}0.23948^{* * *} \\
(7.05)\end{array}$ & $\begin{array}{l}0.15947^{* * *} \\
(6.01)\end{array}$ & $\begin{array}{l}-0.19388^{* * *} \\
(-7.19)\end{array}$ & $\begin{array}{l}0.06233^{* *} \\
(2.6)\end{array}$ & $\begin{array}{l}0.06136^{* * *} \\
(2.85)\end{array}$ & $\begin{array}{l}0.07331^{* *} \\
(2.4)\end{array}$ & $\begin{array}{l}0.01374 \\
(0.64)\end{array}$ \\
\hline Employed & $\begin{array}{l}0.35951^{* * *} \\
-9.86\end{array}$ & $\begin{array}{l}-0.0308 \\
(-0.82)\end{array}$ & $\begin{array}{l}0.34214^{* * *} \\
-8.72\end{array}$ & $\begin{array}{l}*-0.0035 \\
(-0.15)\end{array}$ & $\begin{array}{l}0.05498^{*} \\
(1.94)\end{array}$ & $\begin{array}{l}-0.00891 \\
(-0.35)\end{array}$ & $\begin{array}{l}0.02101 \\
(0.58)\end{array}$ & $\begin{array}{l}-0.03793 \\
(-1.53)\end{array}$ \\
\hline Urban & $\begin{array}{l}0.24150^{* * *} \\
(5.82)\end{array}$ & $\begin{array}{l}0.27612^{* * *} \\
(6.88)\end{array}$ & $\begin{array}{l}0.27106^{* * *} \\
(6.24)\end{array}$ & $\begin{array}{l}0.04752 \\
(1.40)\end{array}$ & $\begin{array}{l}0.03328 \\
(1.19)\end{array}$ & $\begin{array}{l}0.0246 \\
(0.81)\end{array}$ & $\begin{array}{l}-0.00832 \\
(-0.21)\end{array}$ & $\begin{array}{l}-0.0343 \\
(-1.17)\end{array}$ \\
\hline Poor & $\begin{array}{l}-0.85726^{* * *} \\
(-6.61)\end{array}$ & $\begin{array}{l}-0.56094^{* * *} \\
(-2.79)\end{array}$ & $\begin{array}{l}-0.59997^{* * *} \\
(-2.83)\end{array}$ & $\begin{array}{l}0.24786^{* *} \\
(2.07)\end{array}$ & $\begin{array}{l}-0.26221^{* *} \\
(-2.18)\end{array}$ & $\begin{array}{l}-0.14593 \\
(-0.87)\end{array}$ & $\begin{array}{l}-0.18102 \\
(-0.88)\end{array}$ & $\begin{array}{l}0.05851 \\
(0.43)\end{array}$ \\
\hline Constant & $\begin{array}{l}7.12950^{* * *} \\
(57.96)\end{array}$ & $\begin{array}{l}5.91649^{* * *} \\
(66.5)\end{array}$ & $\begin{array}{l}8.80361^{* * *} \\
(47.62)\end{array}$ & $\begin{array}{l}* 1.68644^{* * *} \\
(15.07)\end{array}$ & $\begin{array}{l}5.72661^{* * *} \\
(67.22)\end{array}$ & $\begin{array}{l}5.22123^{* * *} \\
(61.02)\end{array}$ & $\begin{array}{l}7.07598^{* * *} \\
(67.31)\end{array}$ & $\begin{array}{c}\text { * } 1.31686^{* * *} \\
(18.02)\end{array}$ \\
\hline Country dummies & Yes & Yes & Yes & Yes & Yes & Yes & Yes & Yes \\
\hline$N$ & 52,447 & 52,168 & 46,746 & 46,681 & 51,650 & 50,937 & 47,054 & 46,892 \\
\hline$R^{2}$ & 0.036 & 0.009 & 0.1 & 0.064 & 0.002 & 0.002 & 0.004 & 0.003 \\
\hline$R^{2(*)}$ & 0.24984 & 0.15034 & 0.23647 & 0.14662 & 0.24829 & 0.30501 & 0.15001 & 0.14344 \\
\hline \multicolumn{9}{|c|}{ Second stage: current variables } \\
\hline Inflation & $\begin{array}{l}-0.05801^{*} \\
(-1.79)\end{array}$ & $\begin{array}{l}-0.06304^{* *} \\
(-2.36)\end{array}$ & $\begin{array}{l}-0.01061 \\
(-0.36)\end{array}$ & $\begin{array}{l}0.04553^{* * *} \\
(4.22)\end{array}$ & $\begin{array}{l}-0.04692 \\
(-1.54)\end{array}$ & $\begin{array}{l}-0.09577^{* * *} \\
(-3.05)\end{array}$ & $\begin{array}{l}0.01395 \\
(0.52)\end{array}$ & $\begin{array}{l}0.05894^{* * *} \\
(4.82)\end{array}$ \\
\hline Unemployment & $\begin{array}{l}-0.06159 * * * \\
(-5.59)\end{array}$ & $\begin{array}{l}-0.04749^{* * *} \\
(-4.41)\end{array}$ & $\begin{array}{l}-0.03912^{* * *} \\
(-3.07)\end{array}$ & $\begin{array}{l}0.02060^{* *} \\
(2.60)\end{array}$ & $\begin{array}{l}-0.05708^{* * *} \\
(-3.05)\end{array}$ & $\begin{array}{l}-0.06848^{* * *} \\
(-3.85)\end{array}$ & $\begin{array}{l}-0.01504 \\
(-0.69)\end{array}$ & $\begin{array}{l}0.04058^{* * *} \\
(4.20)\end{array}$ \\
\hline No. of countries & 65 & 65 & 65 & 65 & 65 & 65 & 65 & 65 \\
\hline$R^{2}$ & 0.234 & 0.26 & 0.069 & 0.259 & 0.177 & 0.307 & 0.01 & 0.317 \\
\hline$F$-test for inf. = unemp. & 0.01341 & 0.31444 & 0.85204 & 2.77443 & 0.08623 & 0.60882 & 0.61559 & 1.19122 \\
\hline$p$-Value & 0.90818 & 0.57699 & 0.35955 & 0.10083 & 0.77001 & 0.4382 & 0.43568 & 0.27931 \\
\hline \multicolumn{9}{|c|}{ Second stage: lag variables } \\
\hline Lag inflation & $\begin{array}{l}-0.02929 \\
(-0.98)\end{array}$ & $\begin{array}{l}-0.02964 \\
(-1.46)\end{array}$ & $\begin{array}{l}-0.00191 \\
(-0.07)\end{array}$ & $\begin{array}{l}0.02651^{* *} \\
(2.00)\end{array}$ & $\begin{array}{l}-0.02306 \\
(-0.89)\end{array}$ & $\begin{array}{l}-0.06508^{* * *} \\
(-2.84)\end{array}$ & $\begin{array}{l}0.02626 \\
(1.04)\end{array}$ & $\begin{array}{l}0.04819^{* * *} \\
(4.51)\end{array}$ \\
\hline Lag unemployment & $\begin{array}{l}-0.06335^{* * *} \\
(-4.83)\end{array}$ & $\begin{array}{l}-0.05048^{* * *} \\
(-4.25)\end{array}$ & $\begin{array}{l}-0.03832^{* *} \\
(-2.57)\end{array}$ & $\begin{array}{l}0.02325^{* * *} \\
(2.82)\end{array}$ & $\begin{array}{l}-0.05713^{* * *} \\
(-2.69)\end{array}$ & $\begin{array}{l}-0.07072^{* * *} \\
(-3.21)\end{array}$ & $\begin{array}{l}-0.01514 \\
(-0.72)\end{array}$ & $\begin{array}{l}0.04056^{* * *} \\
(4.28)\end{array}$ \\
\hline No. of countries & 65 & 65 & 65 & 65 & 65 & 65 & 65 & 65 \\
\hline$R^{2}$ & 0.199 & 0.191 & 0.067 & 0.184 & 0.15 & 0.272 & 0.023 & 0.32 \\
\hline$F$-test for inf. = unemp. & 1.01542 & 0.67955 & 1.15526 & 0.03438 & 0.8782 & 0.02737 & 1.24545 & 0.23442 \\
\hline$p$-Value & 0.31753 & 0.4129 & 0.28662 & 0.85352 & 0.35233 & 0.86913 & 0.26873 & 0.62997 \\
\hline
\end{tabular}

NOTE: $t$-Statistics are in parentheses. $R^{2}$ corresponds to the between model. $R^{2\left({ }^{*}\right)}$ accounts for the variation explained by the fixed effects. ${ }^{*} p<0.1,{ }^{* *} p<0.05,{ }^{* * *} p<0.01$. 
Table A3

Results of the Single-Stage Approach: Current Inflation and Unemployment

\begin{tabular}{|c|c|c|c|c|c|c|c|c|}
\hline & \multicolumn{4}{|c|}{ Life satisfaction } & \multicolumn{4}{|c|}{ Country situation } \\
\hline & Present & Past & Future & Future-Present & Present & Past & Future & Future-Present \\
\hline Male & $\begin{array}{l}-0.14382^{* * *} \\
(-3.80)\end{array}$ & $\begin{array}{l}-0.00865 \\
(-0.26)\end{array}$ & $\begin{array}{l}-0.14486^{* * *} \\
(-3.49)\end{array}$ & $\begin{array}{l}-0.00911 \\
(-0.38)\end{array}$ & $\begin{array}{l}0.01299 \\
(0.39)\end{array}$ & $\begin{array}{l}-0.08618^{* *} \\
(-2.25)\end{array}$ & $\begin{array}{l}-0.01903 \\
(-0.45)\end{array}$ & $\begin{array}{l}-0.03044 \\
(-1.12)\end{array}$ \\
\hline Age & $\begin{array}{l}-0.05555^{* * *} \\
(-7.86)\end{array}$ & $\begin{array}{l}-0.02477^{* * *} \\
(-4.42)\end{array}$ & $\begin{array}{l}-0.05550 * * * \\
(-6.12)\end{array}$ & $\begin{array}{l}-0.00473 \\
(-0.77)\end{array}$ & $\begin{array}{l}-0.01609^{* * *} \\
(-3.06)\end{array}$ & $\begin{array}{l}0.00194 \\
(0.33)\end{array}$ & $\begin{array}{l}-0.03566^{* * *} \\
(-6.01)\end{array}$ & * $\begin{array}{l}-0.02059^{* * *} \\
(-4.58)\end{array}$ \\
\hline Age $^{2}$ & $\begin{array}{l}0.00049^{* * *} \\
(7.15)\end{array}$ & $\begin{array}{l}0.00034^{* * *} \\
(5.4)\end{array}$ & $\begin{array}{l}0.00018^{* *} \\
(2.05)\end{array}$ & $\begin{array}{l}-0.00027^{* * *} \\
(-4.12)\end{array}$ & $\begin{array}{l}0.00016^{* * *} \\
(2.91)\end{array}$ & $\begin{array}{l}0.00004 \\
(0.7)\end{array}$ & $\begin{array}{l}0.00029 * * * \\
(4.73)\end{array}$ & 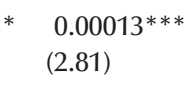 \\
\hline Married & $\begin{array}{l}0.20341^{* * *} \\
(3.79)\end{array}$ & $\begin{array}{l}0.14978^{* *} \\
(2.61)\end{array}$ & $\begin{array}{l}-0.0011 \\
(-0.02)\end{array}$ & $\begin{array}{l}-0.19320^{* * *} \\
(-5.86)\end{array}$ & $\begin{array}{l}-0.08472^{*} \\
(-1.92)\end{array}$ & $\begin{array}{l}-0.09479^{*} \\
(-1.99)\end{array}$ & $\begin{array}{l}0.01012 \\
(0.19)\end{array}$ & $\begin{array}{l}0.09213^{* * *} \\
(2.66)\end{array}$ \\
\hline Employed & $\begin{array}{l}0.58601^{* * *} \\
(8.14)\end{array}$ & $\begin{array}{l}0.13680^{*} \\
(1.9)\end{array}$ & $\begin{array}{l}0.48929 * * * \\
(6.77)\end{array}$ & $\begin{array}{l}-0.07918^{* *} \\
(-2.04)\end{array}$ & $\begin{array}{l}0.26497^{* * *} \\
(4.49)\end{array}$ & $\begin{array}{l}0.25389 * * * \\
(3.15)\end{array}$ & $\begin{array}{l}0.07319 \\
(1.11)\end{array}$ & $\begin{array}{l}-0.18720^{* * *} \\
(-3.86)\end{array}$ \\
\hline Urban & $\begin{array}{l}0.27025^{* * *} \\
(4.32)\end{array}$ & $\begin{array}{l}0.28274^{* * *} \\
(4.48)\end{array}$ & $\begin{array}{l}0.36324^{* * *} \\
(5.42)\end{array}$ & $\begin{array}{l}\text { * } 0.11456^{* *} \\
(2.58)\end{array}$ & $\begin{array}{l}0.09756 \\
(1.23)\end{array}$ & $\begin{array}{l}-0.0416 \\
(-0.57)\end{array}$ & $\begin{array}{l}0.15528^{*} \\
(1.71)\end{array}$ & $\begin{array}{l}0.06906 \\
(1.31)\end{array}$ \\
\hline Poor & $\begin{array}{l}-0.92360^{* * *} \\
(-3.68)\end{array}$ & $\begin{array}{l}-0.74566^{* *} \\
(-2.35)\end{array}$ & $\begin{array}{l}-0.46159 \\
(-1.50)\end{array}$ & $\begin{array}{l}0.51478^{* *} \\
(2.41)\end{array}$ & $\begin{array}{l}-0.0924 \\
(-0.31)\end{array}$ & $\begin{array}{l}-0.31355 \\
(-0.95)\end{array}$ & $\begin{array}{l}0.08347 \\
(0.16)\end{array}$ & $\begin{array}{l}0.20168 \\
(0.7)\end{array}$ \\
\hline Inflation & $\begin{array}{l}-0.07548^{* *} \\
(-2.04)\end{array}$ & $\begin{array}{l}-0.07551^{* *} \\
(-2.53)\end{array}$ & $\begin{array}{l}-0.0324 \\
(-0.94)\end{array}$ & $\begin{array}{l}0.04144^{* * *} \\
(3.62)\end{array}$ & $\begin{array}{l}-0.05884^{*} \\
(-1.87)\end{array}$ & $\begin{array}{l}-0.11252^{* * *} \\
(-3.23)\end{array}$ & $\begin{array}{l}0.00916 \\
(0.33)\end{array}$ & $\begin{array}{l}0.06684^{* * *} \\
(4.99)\end{array}$ \\
\hline Unemployment & $\begin{array}{l}-0.06019^{* * *} \\
(-5.71)\end{array}$ & $\begin{array}{l}-0.04581^{* * *} \\
(-4.62)\end{array}$ & $\begin{array}{l}-0.04100^{* * *} \\
(-3.43)\end{array}$ & $\begin{array}{l}* .01835^{* *} \\
(2.61)\end{array}$ & $\begin{array}{l}-0.05907^{* * *} \\
(-3.42)\end{array}$ & $\begin{array}{l}-0.06764^{* * *} \\
(-4.12)\end{array}$ & $\begin{array}{l}-0.02235 \\
(-1.15)\end{array}$ & $\begin{array}{l}0.03667^{* * *} \\
(4.27)\end{array}$ \\
\hline Constant & $\begin{array}{l}7.82296^{* * *} \\
(30.59)\end{array}$ & $\begin{array}{l}6.55580^{* * *} \\
(29.87)\end{array}$ & $\begin{array}{l}9.16865^{* * *} \\
(34.04)\end{array}$ & $\begin{array}{l}\text { * } 1.39489 * * * \\
(9.77)\end{array}$ & $\begin{array}{l}6.37335^{* * *} \\
(24.33)\end{array}$ & $\begin{array}{l}6.20237^{* * *} \\
(23.5)\end{array}$ & $\begin{array}{l}7.16724 * * * \\
(25.9)\end{array}$ & $\begin{array}{l}0.78952^{* * *} \\
(4.69)\end{array}$ \\
\hline$N$ & 52,447 & 52,168 & 46,746 & 46,681 & 51,650 & 50,937 & 47,054 & 46,892 \\
\hline$R^{2}$ & 0.096 & 0.052 & 0.114 & 0.097 & 0.058 & 0.108 & 0.01 & 0.056 \\
\hline Adjusted $R^{2}$ & 0.095 & 0.052 & 0.114 & 0.096 & 0.058 & 0.107 & 0.01 & 0.056 \\
\hline No. of countries & 65 & 65 & 65 & 65 & 65 & 65 & 65 & 65 \\
\hline F-test for inf. = unemp. & 0.204 & 1.03141 & 0.06423 & 2.62362 & 0.00005 & 1.55137 & 0.80747 & 3.41143 \\
\hline$p$-Value & 0.65304 & 0.31365 & 0.80075 & 0.1102 & 0.99446 & 0.21747 & 0.37224 & 0.06937 \\
\hline
\end{tabular}


Table A4

Results of the Single-Stage Approach: Lag Inflation and Unemployment

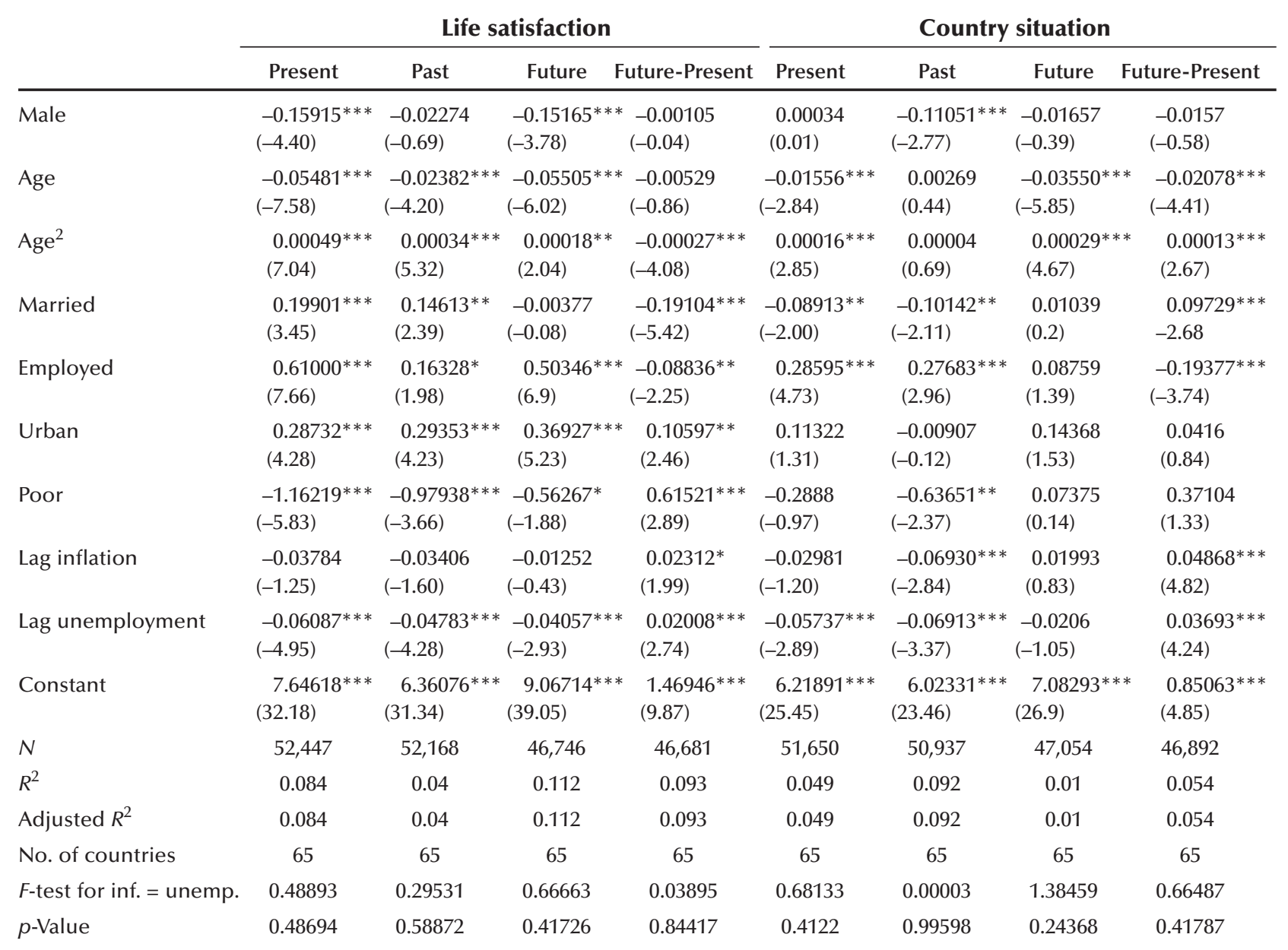

NOTE: $t$-Statistics are in parentheses. $R^{2}$ corresponds to the between model. ${ }^{*} p<0.1,{ }^{* *} p<0.05,{ }^{* * *} p<0.01$. 